\title{
Affective Household Assessment Activities of Electrical Installation Practices
}

\author{
Hantje Ponto, Rudy Sanger \\ Electrical Engineering Department \\ Universitas Negeri Manado \\ Manado, Indonesia
}

\begin{abstract}
In the process of learning electrical installations, practical activities are very important to be carried out so that students have the skills. Affective domain is one aspect of learning. This affective domain affects individual activities in learning activities including the practice of electrical installations. These practice activities need assessment to find out the aspects of the affective domain that students have. The purpose of this study is to develop an affective domain assessment instrument in the practice of electrical installation practices in vocational high schools (SMK). The method used was research and development $(R \& D)$. The results of this study are that this assessment instrument meets the requirements of very valid and practical and effective for use in electrical installation practice activities.
\end{abstract}

Keyword-affective; domain assessment; electrical installation

\section{INTRODUCTION}

Vocational high school (SMK) is one of the formal educations in Indonesia. Education. One characteristic of vocational education is to prepare students to enter the workforce [1]

The aim of vocational education is to produce graduates who are able to open jobs for themselves and others and can work in the industrial world, so that vocational high schools are expected to have special skills in a particular field. One of the special skills implemented in Vocational Schools is the technique of installing electrical installations that are included in the Electrical Engineering expertise program. In the practice of electrical installation practices, students are required not only to have mental skills (cognitive domain) and physical skills (psychomotor domains) but must be supported by an affective domain which is an aspect of soft skills that individuals have. Soft skills will control someone on doing something including learning and work.

Various issues hit SMK because the expected goals were far from expectations, namely that SMK graduates were the largest contribution of unemployment in Indonesia [2]. Competency development in vocational schools in addition to cognitive and psychomotor skills students need to also develop affective domains such as attitudes [3], positive appreciation and work habit [4], a learning habit and creative [5]. Ignoring the affective domain in learning will be detrimental to student development individually and has a broad influence. Students lack the attitudes, interests, value systems and positive appreciation of what they know [6]. In teacher learning activities must arouse students' emotions to take an active role in teaching and learning activities [7]. So that it does not only focus on cognitive and psychomotor aspects but must be integrated with the affective domain. The three domains are intertwined or cannot be separated from one another because they are related and there are parts of each domain overlapping as illustrated in Figure 1.

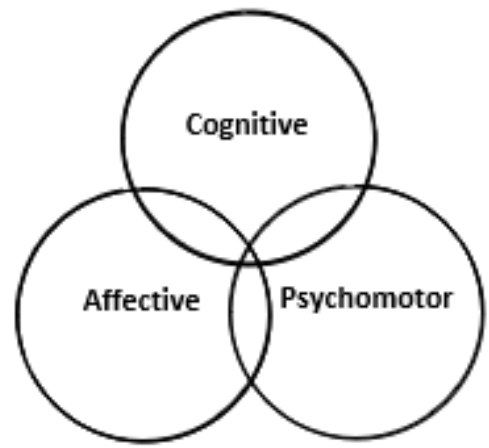

Fig. 1. Integrated cognitive, affective and psychomotor

In this study, assessing the affective domain of students in electrical installation practice activities means that the two domains are integrated.

Affective domain is one of the taxonomies of instructional objectives related to a person's psychological or feelings condition including in learning activities. There are five important affective characteristics, namely "attitudes, interests, self-concept, values and morals" [8] Affective domain determines the success of student learning. Individuals who do not have good affective abilities find it difficult to achieve optimal success. Cognitive and psychomotor learning outcomes will be maximal when affective is high [9].

Affective domains are important for every individual, but their application is still lacking. This happens because 
designing affective learning is not easy. Schools must design appropriate learning activities so that affective learning goals can be achieved [10]. According to Hall [11], simply stated, affective assessment is worthy of the time and effort it requires, and without it, the educational experience is incomplete. There are several methods to measure the affective domain in learning activities including observation methods [12], [13]

Affective domain involves individual emotions which include feelings, values, motivation and attitudes [7], [14-19]. Affective domains are very important for students because they relate to how individuals manage the emotional context of situations that involve others [20].

Affective domain consists of five categories, namely (1) receiving or attending, including awareness, willing to receive, and controlled or selected attention. In this case awareness and sensitivity to something due to stimulation of external stimuli; (2) responding, including responding, ability to answer and satisfaction in answering. This stage students have responded, paying attention to the lessons presented; (3) valuation, including: acceptance of a value, preference of a value, and commitment. This stage the behavior of the students has received and the conformity of the values and consistency; (4) organization, including: conceptualization of value, organization of a value system. This stage is to unify different values, overcome conflicts between values and internally form a consistent value system; (5) characterization by value complex, covering: generalized set and characterization. This level is the stage of internalization of a value system that has been formed in students and can control their behavior in a long period of time so that the characteristics of life views are formed [21], [13], [14], [22].

According to Anderson [13] behavior in the affective domain there are two criteria to be classified, namely: behavior involving one's emotional feelings, and typical individual behavior. There are five types of affective domain characteristics, namely (1) attitude, including the tendency to act like means to be positive or dislike means to be negative towards subjects and teachers; (2) interest, including attention or desire to participate in learning activities; (3) selfconcept, including: individuals can evaluate their abilities and weaknesses; (4) values, including beliefs in actions, actions, good and bad behavior; and (5) morality, including honesty, integrity, fairness and freedom.

The teacher must evaluate the affective domain of students during the learning activities. Before conducting an evaluation, accurate data is needed, while the data can be obtained from an assessment instrument. Thus, the assessment is very important in order to obtain accurate data for evaluation purposes. Assessment is a process of gathering information needed for decision making [23]. [24] said that assessment is an activity of interpreting or describing measurement results. Many experts say that assessment is a process obtained from measurement results [25] [26];[27]: [28]. Based on literature studies obtained five indicators to assess the affective domain, namely: (1) attitude, (2) interest, (3) self-concept, (4) value, and (5) moral.

Based on the preliminary survey, teachers who teach electrical installation training courses in the electricity engineering study program in Vocational Schools in North Sulawesi did not have the instruments to assess the affective domain. This instrument is needed to obtain information about students' behavior in conducting learning activities, especially regarding electrical installation practice activities. Practical activities in these subjects' students must be positive, the willingness and desire to practice, communicate, work together in groups, must be careful so that the results are neat and avoid the risk of accidents, and honesty. The same thing was found by [29], namely the fact that SMK teachers do not have the instruments to measure the affective domain. Assessments made must have clear references so that they can be assessed in a structured and planned manner.

In connection with these problems, in this study is to develop an affective domain assessment in electrical installation practice activities.

\section{RESEARCH METHODS}

This research was carried out in North Sulawesi. The research objective is to develop products for affective domain assessment instruments for use in electrical installation practice activities. In this case to assess and measure aspects of the affective domain of students in conducting electrical installation practices.

The method used is research and development ( R \& D) of ADDIE (Analysis, Develop, Implement, and Evaluate) models developed by Reiser and Mollenda. The stages of this research are:

First, Analysis, is a process for analyzing needs about identifying problems and literature studies;

Second, Design, design products in draft form. In this study designing an affective domain assessment of indicators based on theoretical studies then continued with designing instrument items accompanied by determining the rating scale. Assessment items or assessed aspects consist of: (1) timely entering the practice room, (b) paying attention to the material presented by the teacher, (3) obeying the teacher's instructions, (4) having the willingness to practice, (5) working happily, (6) communion, (7) trying to train themselves, (8) confidence, (9) thoroughness, (10) working together in groups, (11) acknowledging friends' excesses, (12) using practical clothes , (13) obeying the rules of practice, (14) honesty, (15) ethical manners, and (16) organize / tidy up the practice room.

Third, Development, is a stage to produce products. In this study, the instrument has formed one into several affective domain assessment rubrics for electrical installation practice activities.

Fourth, Implementation, is the development products will be validated by 2 experts including measurement and 
evaluation experts in the field of electrical engineering, and electrical installation teachers in vocational schools. Validation criteria were shown in Table I.

TABLE I. VALIDITY TESTING CRITERIA

\begin{tabular}{|c|c|}
\hline Range & information \\
\hline $\mathrm{V}>4.5$ & Very valid \\
\hline $3.5<\mathrm{V} \leq 4,5$ & Valid \\
\hline $3.0<\mathrm{V} \leq 3.5$ & Quite valid \\
\hline $2.5<\mathrm{V} \leq 3.0$ & Less valid \\
\hline$\leq 25$ & Invalid \\
\hline
\end{tabular}

Validity is calculated using the formula as follows:

$$
V=\frac{\sum M}{n}
$$

Where: $\mathrm{V}=$ level of validity, $\Sigma \mathrm{M}=$ total mean, and $\mathrm{n}=$ number of items.

The product trial subjects were teachers who taught subjects of electrical installation practices. In this trial the teacher used a draft product to assess students' soft skills in electrical installation practice activities. The instrument rubric uses a Likert scale, which is very good (5), good (4), good enough (3), not good (2), and very bad (1). Criteria for evaluating the practicality and effectiveness of products were shown in tables 2 and 3. After the product meets the requirements for validity, a trial is continued to determine the practicality and effectiveness of the product. The subjects who will conduct the trial are the teachers who teach the electrical installation training. The trial process is that the teacher instructs students to practice then the teacher uses this assessment instrument to assess the affective domain of students. Practical testing criteria were stated in table II.

TABLE II. Practical Testing CRiteria

\begin{tabular}{|c|c|}
\hline Range & Information \\
\hline $\mathrm{P}>4.5$ & Very practical \\
\hline $3.5<\mathrm{P} \leq 4,5$ & Practical \\
\hline $3.0<\mathrm{P} \leq 3.5$ & Quite practical \\
\hline $2.5<\mathrm{P} \leq 3.0$ & Less practical \\
\hline $\mathrm{P} \leq 25$ & Not practical \\
\hline
\end{tabular}

Practicality of using products to assess students' soft skills in various activities that use the following measurements as follows:

$$
P=\frac{\sum S}{n}
$$

$\mathrm{P}=$ practicality level, $\Sigma \mathrm{S}=$ total practicality score, and $\mathrm{n}=$ many assessors.

Product effectiveness can be seen in table III.

TABLE III. EFFECTIVENESS TESTING CRITERIA

\begin{tabular}{|c|c|}
\hline Range & Remarks \\
\hline $\mathrm{E}>4.5$ & Very effective \\
\hline $3.5<\mathrm{E} \leq 4,5$ & Effective \\
\hline $3.0<\mathrm{E} \leq 3.5$ & Quite effective \\
\hline $2.5<\mathrm{E} \leq 3.0$ & Less effective \\
\hline $\mathrm{E} \leq 25$ & Ineffective \\
\hline
\end{tabular}

Product effectiveness is calculated using the following:

$$
E=\frac{\sum S}{n}
$$

$\mathrm{E}=$ level of effectiveness, $\Sigma \mathrm{S}=$ total value of effectiveness, and $\mathrm{n}=$ many assessors.

Fifth, Evaluation, the last stage is evaluating the product. Evaluation activities in this study to improve products based on information obtained from the results of the trial of product weaknesses.

\section{RESULT AND DISCUSSION}

As has been explained that for product validity testing, it is validated by one expert in measurement and evaluation of electrical engineering education and one teacher in an electrical installation at a vocational school. Validation data is shown in table IV.

TABLE IV. PRODUCT VALIDATION BY EXPERTS

\begin{tabular}{|c|c|c|c|}
\hline \multirow{2}{*}{ No. Item } & \multicolumn{2}{|c|}{ Appraiser Score } & \multirow{2}{*}{ Mean } \\
\cline { 2 - 3 } & Expert 1 & Expert 2 & \\
\hline 1 & 5 & 5 & 5 \\
\hline 2 & 5 & 5 & 5 \\
\hline 3 & 5 & 4 & 4.5 \\
\hline 4 & 5 & 5 & 5 \\
\hline 5 & 5 & 5 & 5 \\
\hline 6 & 5 & 5 & 5 \\
\hline 7 & 5 & 5 & 5 \\
\hline 8 & 4 & 5 & 4.5 \\
\hline 9 & 5 & 5 & 5 \\
\hline 10 & 5 & 5 & 5 \\
\hline 11 & 5 & 5 & 5 \\
\hline 12 & 5 & 5 & 5 \\
\hline 13 & 5 & 5 & 5 \\
\hline 14 & 5 & 5 & 5 \\
\hline 15 & 5 & 4 & 4.5 \\
\hline 16 & 5 & 5 & 5 \\
\hline \multicolumn{3}{|c|}{ Total mean $(\Sigma M)$} & \\
\hline
\end{tabular}

By using the formula [1] it is obtained $\mathrm{V}=4.9$. Based on the criteria for testing the validity stated in table 1 shows that $\mathrm{V}=4.9>4.5$. Thus, the affective domain assessment to be used in the electrical installation practice categorized as very valid.

Furthermore, the trial subjects were practical and the effectiveness of the product was carried out on 12 teachers of the electrical engineering study program. Practical trial results data can be seen in table $\mathrm{V}$.

TABLE V. TeSt Data For Product Practicality

\begin{tabular}{|c|c|}
\hline Teacher & Score \\
\hline 1 & 5 \\
\hline $\mathrm{x} 2$ & 4 \\
\hline 3 & 5 \\
\hline 4 & 5 \\
\hline 5 & 5 \\
\hline 6 & 4 \\
\hline 7 & 5 \\
\hline 8 & 4 \\
\hline 9 & 5 \\
\hline 10 & 5 \\
\hline
\end{tabular}




\begin{tabular}{|c|c|}
\hline Teacher & Score \\
\hline 11 & 4 \\
\hline 12 & 5 \\
\hline Total score $(\Sigma \mathrm{S})$ & 56 \\
\hline
\end{tabular}

After using the formula [2], the practicality value $\mathrm{P}=4.7$ is obtained. Based on table 2, the practicality score is included in the classification $P=4.7>4.5$. This shows that the developed assessment meets very practical requirements.

While the results of the trial data test the effectiveness of the product are stated in table VI.

TABLE VI. TeSt Data ON Product EFFectivenEsS

\begin{tabular}{|c|c|}
\hline Teacher & Score \\
\hline 1 & 4 \\
\hline 2 & 5 \\
\hline 3 & 5 \\
\hline 4 & 4 \\
\hline 5 & 4 \\
\hline 6 & 4 \\
\hline 7 & 5 \\
\hline 8 & 5 \\
\hline 9 & 4 \\
\hline 10 & 5 \\
\hline 11 & 4 \\
\hline 12 & 4 \\
\hline Total score $(\Sigma S)$ & 53 \\
\hline
\end{tabular}

The results of calculations using the formula [3] obtained $\mathrm{E}=4.4$. From table 3 shows that the value of effectiveness is in the category between $3.5<\mathrm{E} \leq 4.5$. This shows that the assessment products developed are effective.

\section{CONCLUSION}

Based on the results of the study, it was concluded that:

- First, the affective domain assessment instrument of students in the practice of electrical installation practices is valid;

- Second, affective domain assessment products development is very practical for teachers to use in electrical installation practices; and

- Third, affective domain assessment results of effective development are used by teachers in electrical installation practice activities.

\section{REFERENCES}

[1] P.W. Widarto, "Pengembangan model pembelajaran soft skill dan hard skill untuk siswa SMK," Cakrawala Pendidik., vol. 31, no. 3, pp. 409423, 2012.

[2] D. Andreas, "Mengapa pengangguran terbanyak justri lulusan SMK?," [Online]. Available: https://tirto.id/mengapa-pengangguranterbanyak-justru-lulusan-smk-cJ6Y, 2018.

[3] S. A. Stumpf, "Promotion to partner the importance of relationship competencies and interpersonal style," Career Dev. Int., vol. 14, no. 5, pp. 428-440, 2009.

[4] W. R. Heinz, "Redefining the Status of Occupations.," in International Handbook of Career Guidance, R. V. E. J. A. Athanasou, Ed. Springer Science Business Media B.V., 2009.

[5] A. Gill, I.S., Fluitman, F., \& Dar, Vocational Education and Training Reform, Matching Skills to Markets and Budgets. Washington, DC: Oxford University Press., 2000.
[6] Suyanto, Refleksi Dan Reformasi Pendidikan Di Indonesia Memasuki Millenium III. Yogyakarta: Adicita Karya Nusa, 2010.

[7] A.E. Woodfolk, Educational psychology. USA: Allyn and Bacon, 1995.

[8] Depdiknas, "Pengembangan Perangkat Penilaian Afektif," Jakarta, 2008.

[9] W.J. Popham, Popham.pdf. Boston: Allyn and Bacon, 1995.

[10] Amri, "Pengembangan instrumen penilaian ranah afektif pada pembelajaran biologi di SMA," J. Biotek, vol. 4, no. 1, pp. 52-69, 2016.

[11] R.A. Hall, "Affective Assessment: The Missing Piece of the Educational Reform Puzzle," Delta Kappa Gamma Bull., vol. 77, no. 2, pp. 2011, 2011.

[12] B. Anderson, The Complete Thinker: A Handbook of Theniques For Creative and Critical Problem Solving. New Jersey: Englewood Cliffs., 1980.

[13] L.W. Anderson, Assessing affective characteristic in the schools. Boston: Allyn and Bacon, 1981.

[14] D.R. Anderson, L. W. \& Krathwohl, A Taxonomy for Learning, Teaching, and Assessing: A Revision of Bloom's Taxonomy of Educational Objectives. . New York: Longman, 2001.

[15] S. Bharuthram, "Attending to the affective: Exploring first year students' emotional experiences at university," South African J. High. Educ., vol. 32, no. 2, pp. 27-42, 2018.

[16] D.R. Bloom, B.S. Engelhart, M.D. Furst, E.J. Hill, W.H. Krathwolh, Taxonomy of educational objectives: The classification of educational goals. Handbook I: Cognitive domain. New York: David McKay., 1956.

[17] B.S. Bloom, Taksonomy of Educational Objectives (The Clasification of Educational Goals) Handbook 1 Cognitive Domain. London: Longman Group Ltd., 1979.

[18] S M. Gronlund and N.E. Brookhart, (2009). Writing instructional objectives (8th ed.)., 8th ed. Upper Saddle River, NJ: Pearson Education., 2009.

[19] B.B. Krathwolh, D.R. Bloom, B.S. Masia, Taxonomy of educational objectives (Handbook II: Afektif Domain). New York: David McKay., 1964.

[20] C. ParmD, A.J.M. PharmD, K.L. Green, "Instructional design and assessment. Emphasizing Bloom's Affective Domain to Reduce Pharmacy Students' Stigmatizing Attitudes.," Am. J. Pharm. Educ., vol. 81, no. 2, pp. 1-7, 2018.

[21] J. C. Anderson, L. W. \& Anderson, "Affective assessment is necessary and possible.," Educ. Leadersh., vol. 39, no. 7, pp. 524-526, 2006.

[22] N.E. Gronlund, Writing instructional objectives for teaching and assessment, 7th ed. Upper Saddle River, NJ: Merrill Prentice Hall., 2004.

[23] T. Overton, Assessing Learners with Special Needs: An Applied Approach, 7th ed. Brownsville: University of Texas., 2008.

[24] M. Djemari, Pengukuran Penilaian \& Evaluasi Pendidikan. Yogyakarta: Nuha Medika, 2012.

[25] J.S. 1995. Calongesi, Merancang Tes untuk Menilai Prestasi Siswa. Bandung: Institut Teknologi Bandung., 1995.

[26] Firman, Penilaian Hasil Belajar dalam Pengajaran Kimia. Bandung: Jurusan Pendidikan Kimia FPMIPA Universitas Pendidikan Indonesia.., 2000.

[27] Mulyasa, Praktik penelitian tindakan kelas. Bandung: Rosdakarya, 2009.

[28] Purwanto, Evaluasi hasil belajar. Yogyakarta: pustaka pelajar, 2013.

[29] T. Kusumawati, "Pengembangan instrumen penilaian afektif mata pelajaran aqidah akhl'lak.," J. Smart, vol. 1, no. 1, pp. 111-123, 2015. 